\title{
Comparing the Effectiveness of Cognitive Behavioral Couple Therapy and EIS Model on Sexual Function, Among Pregnant Women
}

\author{
Mohammad Amini $^{1}$, Mahmoud Guodarzi ${ }^{2 *}$, Shole Shahgheibi ${ }^{3}$
}

1. PhD Student, Department of Counseling, Sanandaj Branch, Islamic Azad University, Sanandaj, Iran

2. Asisstant Professor, Department of Family Counseling, Sanandaj Branch, Islamic Azad University, Sanandaj, Iran

3. Professor, Department of Obstetrics and Gynecology, Faculty of Medicine, Kurdistan University of Medical Sciences, Sanandaj, Iran

\begin{tabular}{|c|c|}
\hline Article Info & ABSTRACT \\
\hline $\begin{array}{l}\text { Received: 2020/11/08; } \\
\text { Accepted: 2021/03/03; } \\
\text { Published Online: 2021/09/21 }\end{array}$ & $\begin{array}{l}\text { Introduction: Pregnancy causes many physical and psychological changes. Therefore, } \\
\text { pregnant women may face many issues and problems, including a lack of reduced sexual } \\
\text { function. This study was prepared to compare the effectiveness of cognitive-behavioral couple } \\
\text { therapy training and the EIS (empathy, intimacy, and sexual satisfaction) model on sexual } \\
\text { function in pregnant women. }\end{array}$ \\
\hline
\end{tabular}

10.30699/ajnmc.29.3.233

Original Article

Use your device to scan and read the article online

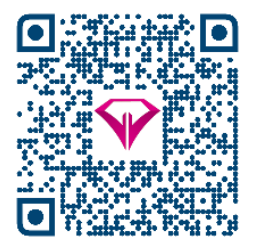

Methods: This was a semi-experimental study with pre- and post-test design. A total of 60 people among the statistical population, who met the inclusiojn criteria were chosen, and randomly divided into three groups of 20 (two intervention groups and one control group). The intervention participants were trained using cognitive-behavioral and EIS model in 8 sessions of 90 minutes, while the control group did not receive any training during this time. The tool used to collect data in pre- and post-test was the Women's Sexual Performance Index (FSFI). Data were analyzed using SPSS 23 at a significance level of 0.05 .

Results: Findings showed that both cognitive-behavioral approaches and the EIS model are practical on sexual function and its subscales (sexual desire, sexual arousal, vaginal moisture, orgasm, sexual satisfaction, painful intercourse) $(P$ value $<0.05)$. There is a difference in their effectiveness in this regard. The EIS model with a mean and standard deviation of $24.08 \pm 1.85$ had a more significant effect on sexual function than the cognitive-behavioral approach with a mean and variation of $17.58 \pm 1.1$.

Conclusion: Therefore, it can be concluded that despite the differences between these two approaches (cognitive-behavioral approaches and EIS model), both are useful in terms of sexual function and its subscales. However, due to the greater effectiveness of the EIS model, it can be used during pregnancy besides the other cares.

Keywords: Pregnant women, Sexual function, Cognitive-behavioral, EIS model

Corresponding Information:

Mahmoud Guodarzi, Asisstant Professor, Department of Family Counseling, Sanandaj Branch, Islamic Azad University, Sanandaj, Iran. Email mg.sauc@gmail.com

Copyright ( 9 2021, This is an original open-access article distributed under the terms of the Creative Commons Attribution-noncommercial 4.0 International License which permits copy and redistribution of the material just in noncommercial usages with proper citation.

How to Cite This Article:

Amini M, Guodarzi M, Shahgheibi S. Comparing the Effectiveness of Cognitive Behavioral Couple Therapy and EIS Model on Sexual Function, Among Pregnant Women. Avicenna J Nurs Midwifery Care. 2021; 29 (3):233-244 


\section{مقايسة اثربخشى آموزش زوجدرمانى شناختى ـرفتارى و مدلEIS بر عملكرد جنسى در زنان باردار محمد امينى'، محمود گودرزى *'، شعله شاغيبى}

ا. دانشجوى دكترى، گروه مشاوره، واحد سنندج،دانشگاه آزاد اسلامى، سنندج، ايران

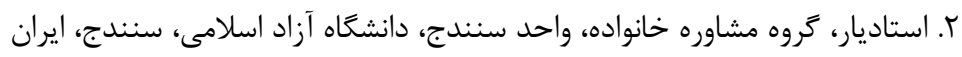

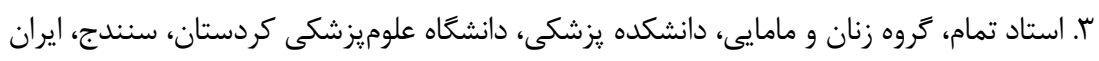

\begin{tabular}{|c|c|}
\hline جكيده & اطلاعات مقاله \\
\hline 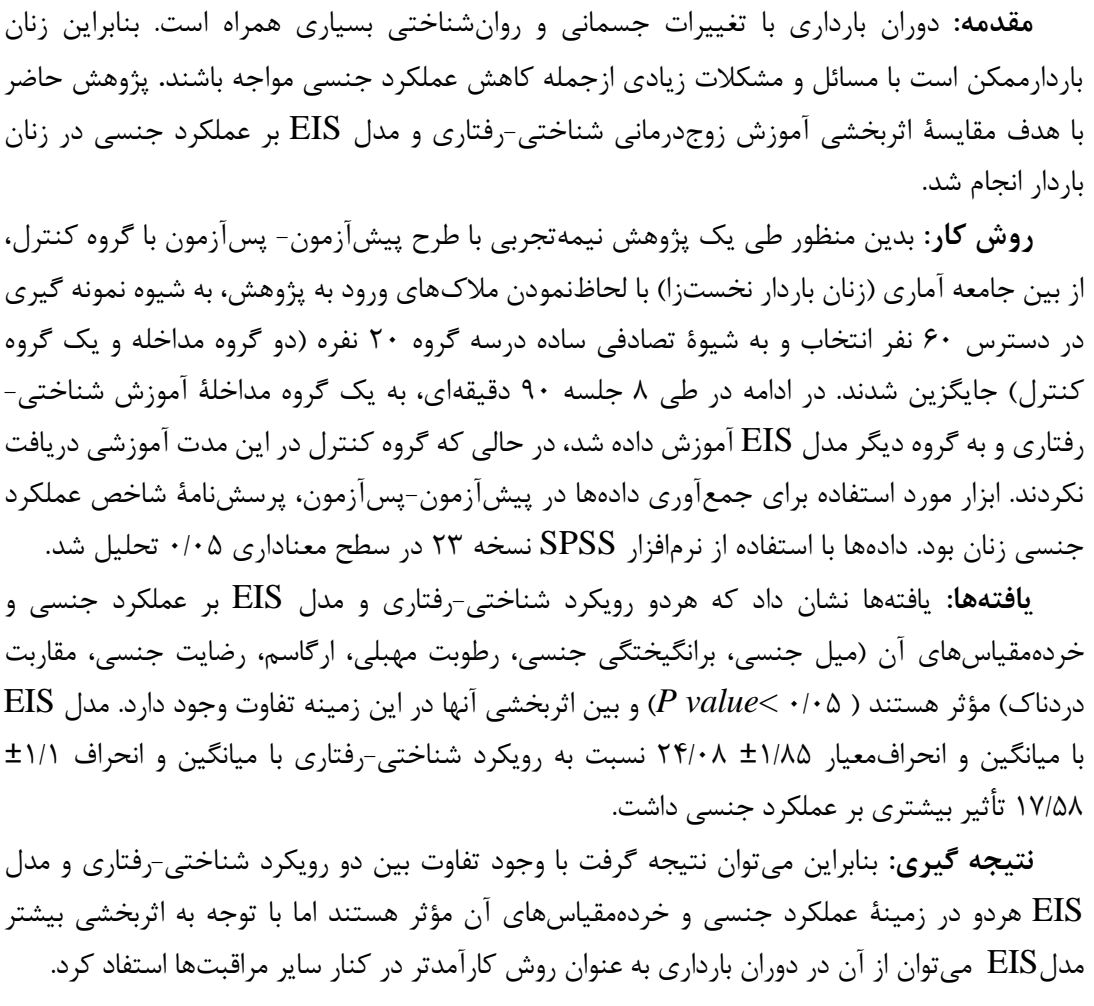 & 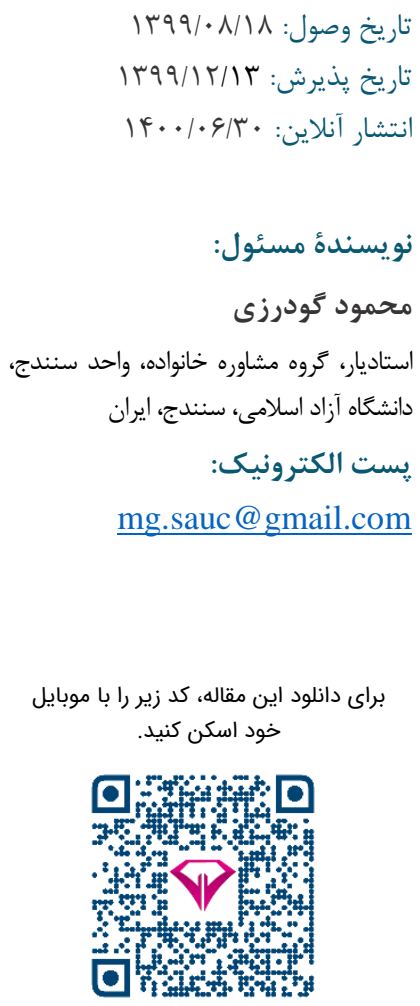 \\
\hline كليدوازهها: زنان باردار، عملكرد جنسى، رويكرد شناختى - رق & \\
\hline
\end{tabular}

مقدمه - - مقد

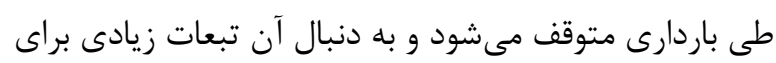

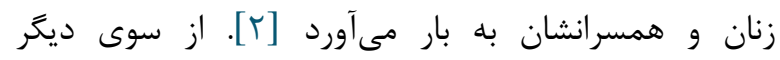

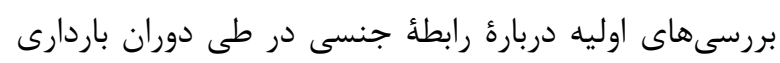

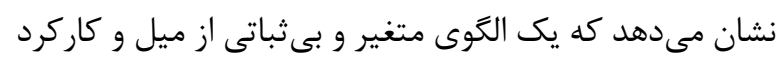

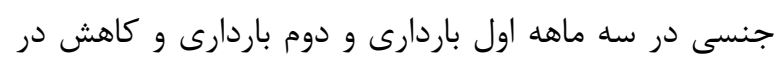

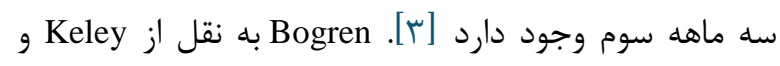

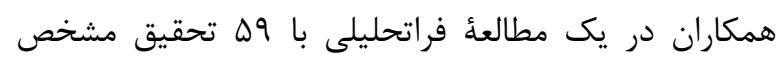

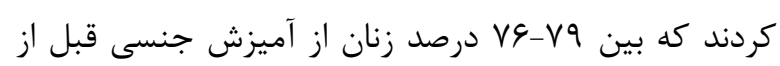
باردارى لذت مىبرند؛ در حالى كه اين وضعيت پِّ از باردارى إن
باردارى يكى از عواملى است كه با ايجاد تغييرات جسمى

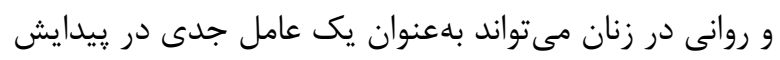

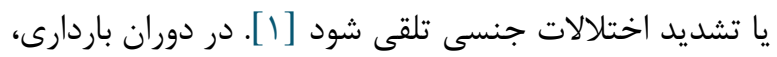

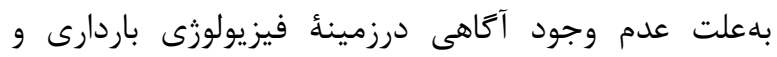

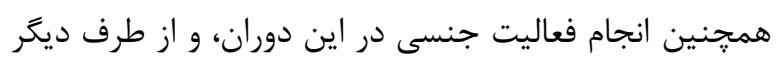

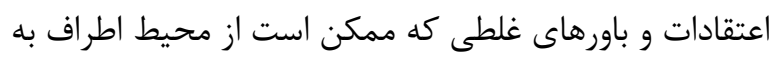

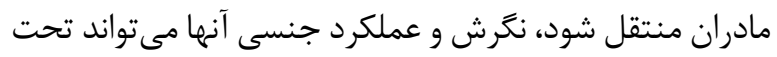

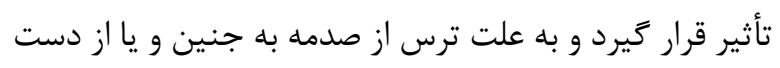

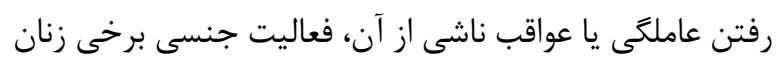


جنسى و زناشويى از طريق صميميت و همدلى و تجربه و آكاهى از هيجانات، بر بُعد معنويت و اعتقادات مذهبى در بهبوديود

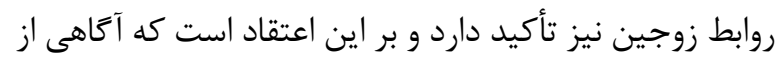
باورها و ارزشهاى مذهبى و معنوى در رابطه با زوجين و نقش دئ دئ هر يك از آنها در روابط خانوادگى، جنسى و زناشويى مى تواند

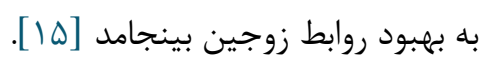
در اين راستا، مطالعات انجام شده، آموزش زوجين زوددرمانى شناختى-رفتارى را به عنوان شيوهاى مناسب بر عملكرد

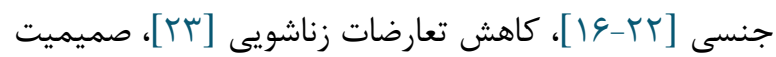
زناشويى [YT] مطرح نمودهاند. در يزوهشى ديخر Goudarzi و Boostanipoor در افزايش سازگازى زناشويى را نشان دادند [rه]. علاوه بر

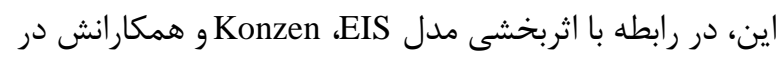
يزوهش خود به اين نتيجه رسيدند كه به كارگيرى مدل EIS موجب رضايت جنسى، صميميت زناشويى و صميميت جنسى

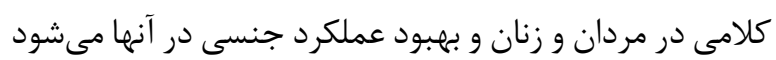
$\left[1 \mathrm{l}^{\mathrm{f}}\right]$

هرجند تحقيقات زيادى درزمينه اثربخشى رويكرد

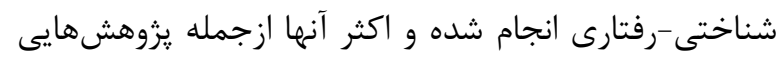
كه در بالا به آن اشاره شد كارايى آن رام را درزمينهُ رضايت زناشويى، رضايت جنسى، كاهش تعارضات و افزايش سازگارى زناشويى، كاهش استرس، افسردگى، اضطراب، و سلامت روانى

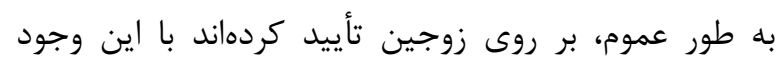

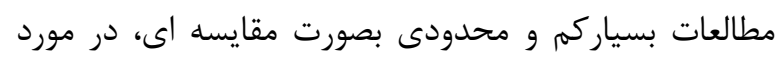
تأثير اين رويكرد و مقايسٔ اثربخشى آن با يك رويكرد نو درزمينهُ عملكرد جنسى در زنان باردار در دسترس است. بر اين اساس و بنا به اهميت و ضرورت دستيابى به مؤثرترين شيوء افزايش عملكرد جنسى زنان باردار با توجه به تأثيرات

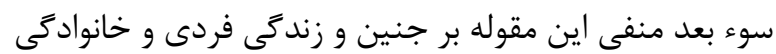
زنان باردار، انجام اين تحقيق لازم و ضرورى به نظر مى بعرسد.

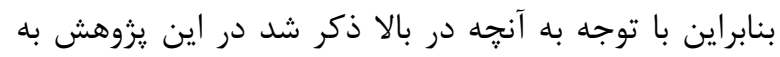
دنبال ياسخگويى به اين سؤال كلى هستيم كه به آآيا ميان

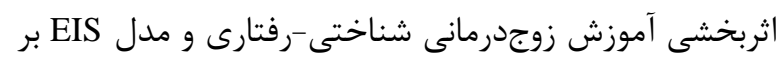
عملكرد جنسى زنان باردار تفاوت وجود دارد؟

${ }^{r}$ Empathy, intimacy, and sexual satisfaction:EIS
به 99 درصد در سه ماهئ اول، VD-AF درصد در سه ماهئ دوم

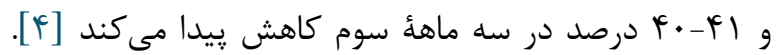
يزوهشهاى انجام شده ديخر نيز درزمينهُ عملكرد جنسى زنان

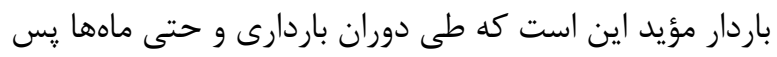

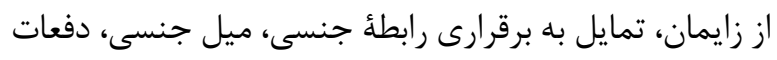

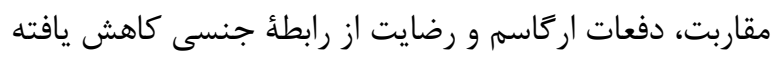

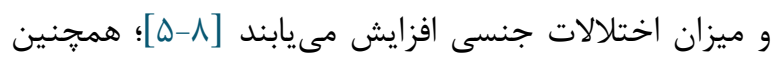

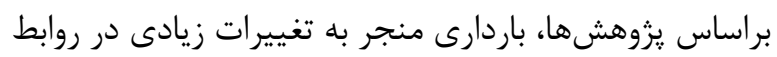
عاطفى، جنسى و رضايت زناشويى زوجين مىشود [1 ا -9].

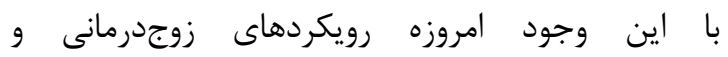
خانوادهدرمانى گوناگونى با هدف كاهش تعارضات و آشفتخى ارتباطى ميان زوجها و كمك به آنها در حل مشكلات و تصميمى گيرىهاى درست به وجود آمده است؛ ازجملة اين

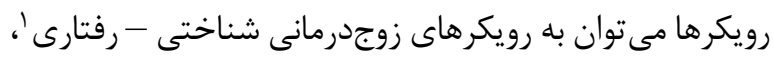
و مدل همدلى، صميميت، رضايت جنسى ب اشاره نمود.

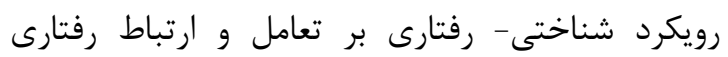
زوجين و رفتارهاى مشكلزا و آكاهى از آنها، توضيح و تشريح رابطءٔ بين افكار و احساسات و رفتار افراد، تغيير توقعات، باورها و خطاهاى شناختى و شناختهاى غير واقعى زوجين و و رونين بازسازى و تصحيح شناختها و انتسابهاى نادرست درى

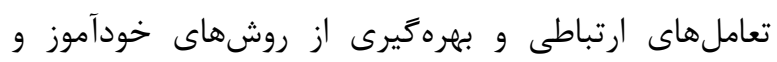
آموزش مهارتهاى ارتباطى و حل مسئله در تعاملهاى

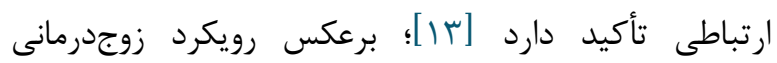
شناختى- رفتارى كه يك رويكرد شناختهشده درزمينئ

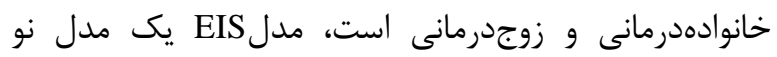

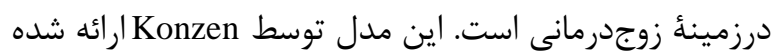

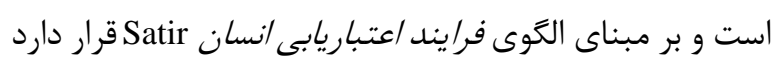

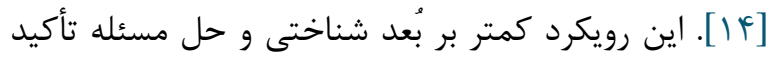
دارد و بيشتر بر تجربه، شناسايى و آكاهى از هيجانات و و ودئ ارتباطات و واكنش هاى هيجانى زوجين و اصلاح و بازسازى و رشد واكنشهاى هيجانى در فضايى توام با خلوص و همدلى رئى در زمان حال متمركز است و از اين راه مى خواهد ضمن افزايش خودشناسى و بهبود عزتنفس و ارزش شخصى، به اصلاح ارتباطات آسيبيذير، بهبود صميميت نسبى، حل تعارضات،

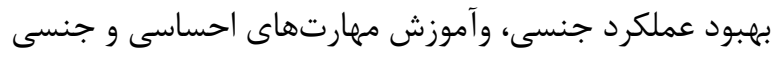
بيردازد؛ همجنين اين مدل زوجدرمانى علاوه بر افزايش رضايت

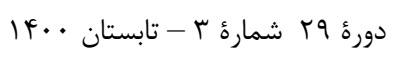

CBT.' 
ياسخ داده شد و در نهايت از آنها رضايتنامهُ آكاهانهُ كتبى

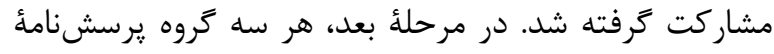
FSFI

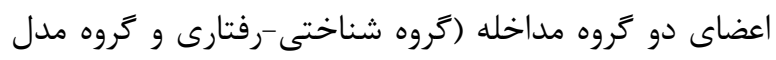
(EIS

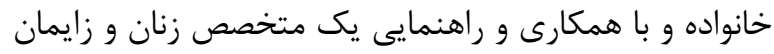

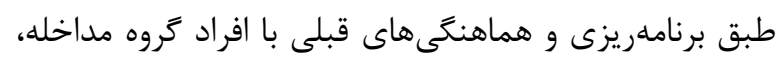

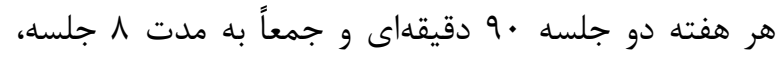
مطابق يروتكلهاى ارائه شده براى هر كدام از شيوههاى

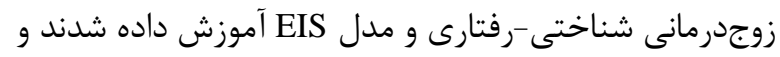

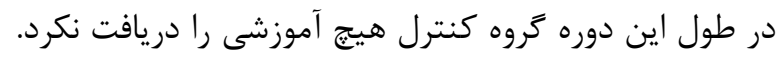

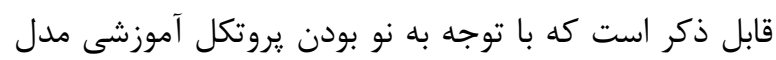
EIS

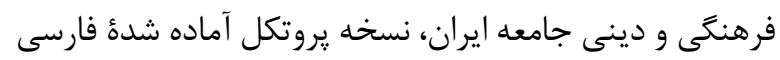

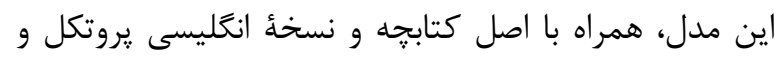

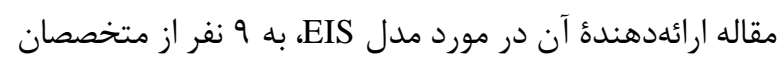
و صاحبنظران برجستهُ خانوادهدرمانى با حداقل • •ا سال

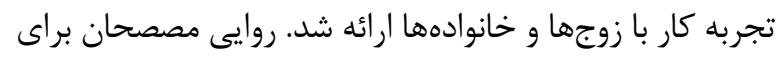

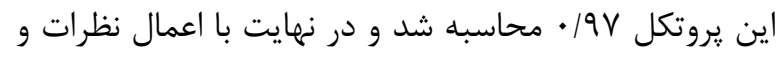

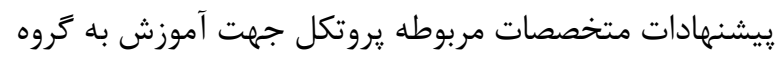

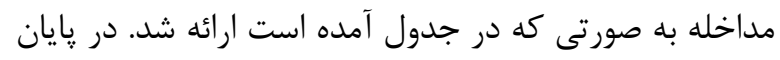

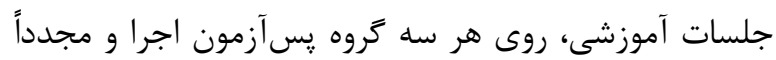

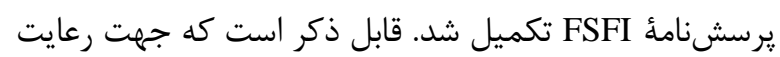

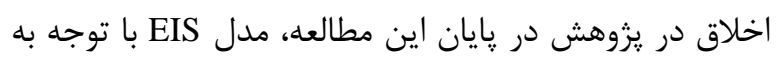

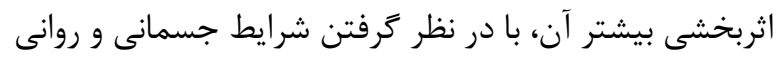

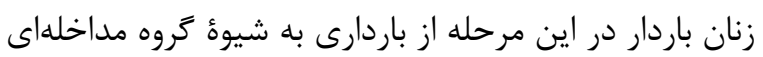

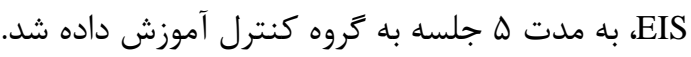

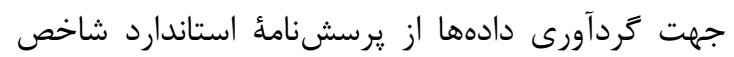

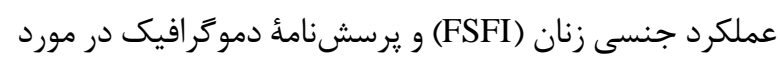

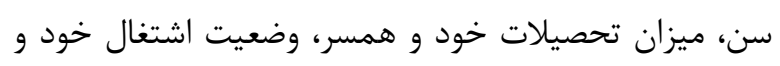

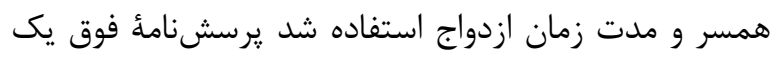
شاخص ششُبعدى است كه عملكرد جنسى زنان ازدوان را را به وسيله

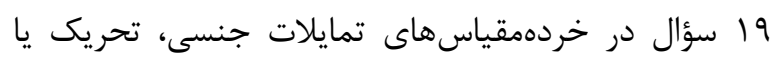

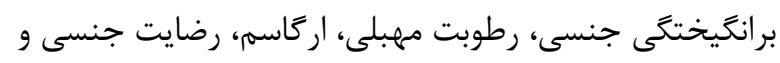

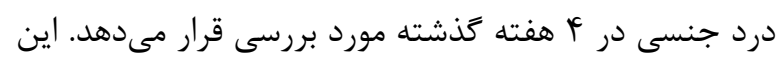

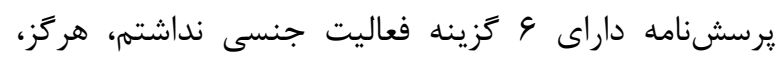
بندرت، كاهى، اغلب، هميشه است كه از صفر تا له نمره كذارى مىشود نمرات در نظر كرفته شده براى سؤالهاى حميطه كئه ميل
روش كار

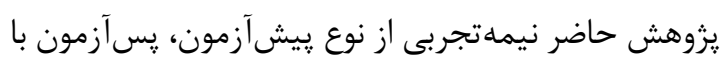

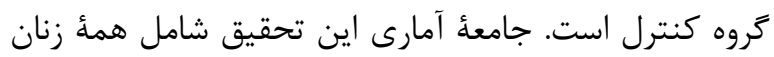

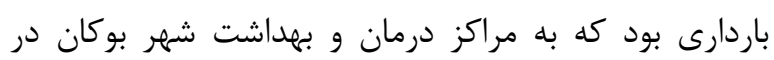

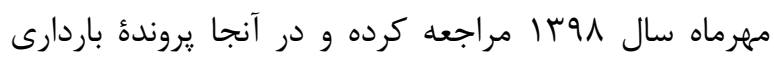

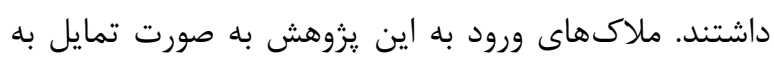

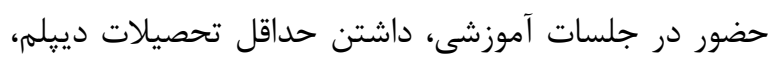

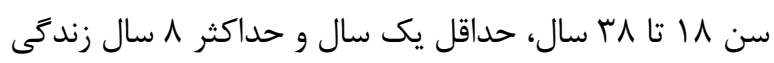

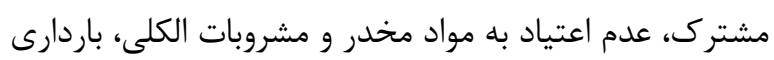

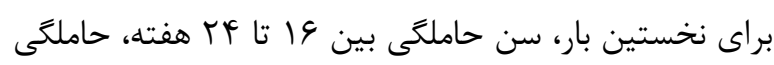

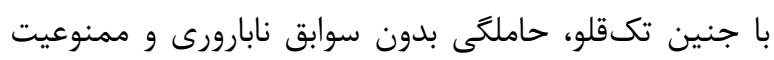

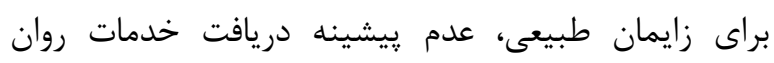

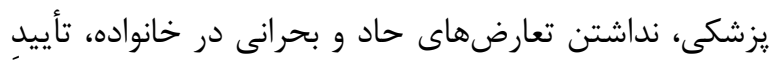

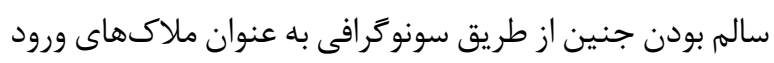

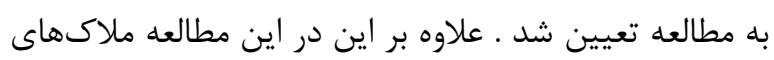

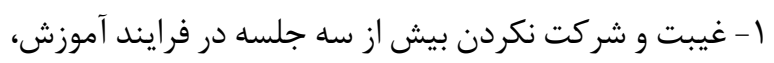

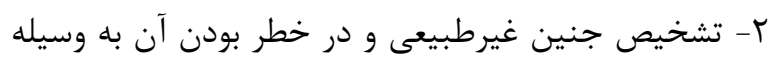

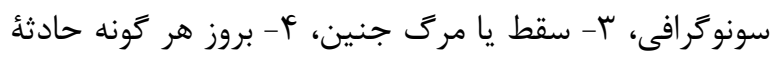

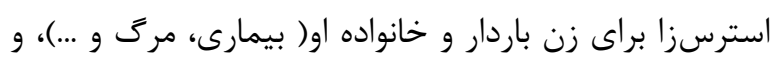

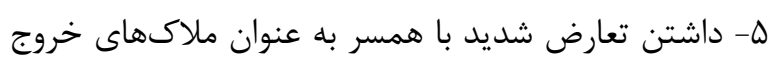
اعضا از يزوهش در نظر كرفته شد.

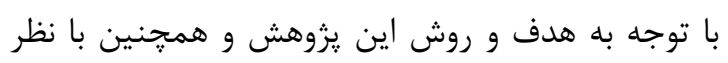

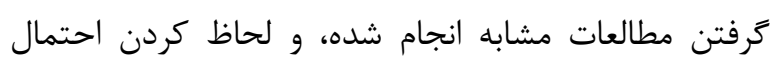

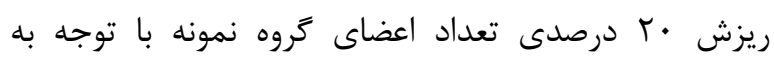

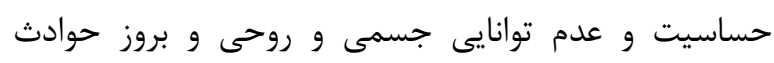

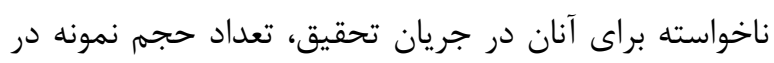

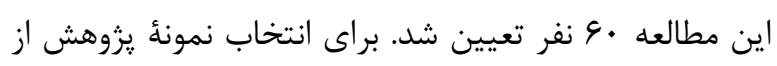

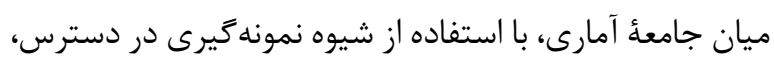

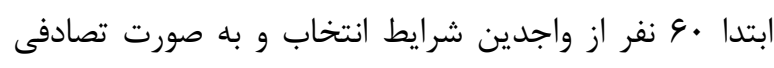

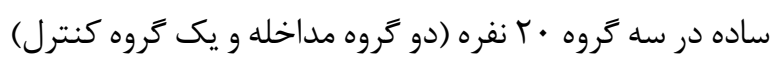

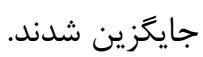

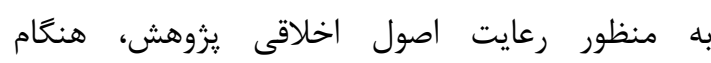

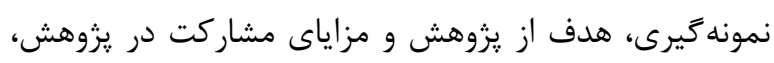

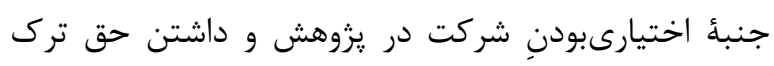

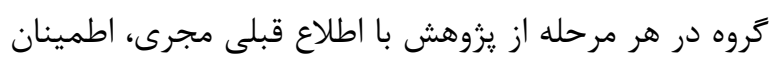

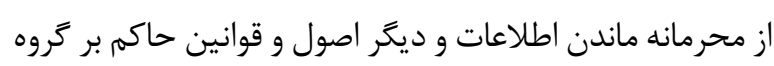

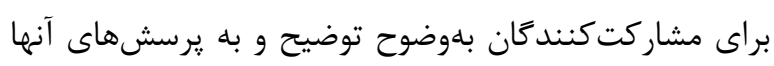


جنسى مطلوب، و برعكس نمره پايين نشاندهنده عملكرد جنسى نامطلوب است. نقطهُ برش جهت تعيين اختلال عملكرد

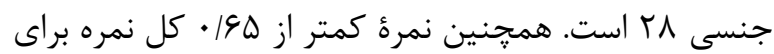
هر حيطه، اختلال عملكرد آن حيطه در نظر رَفته مى هـود. جدول زير سيستم نمرهدهى : يرسشنامئ شاخص عملكرد

$$
\text { جنسى زنان را نشان مى دهد: }
$$

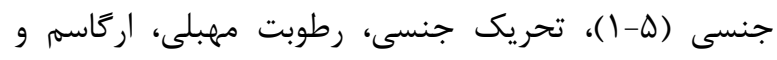

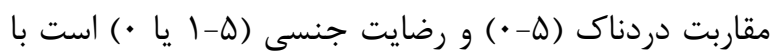
جمع نمرات فرد در هر حيطه و ضرب آن در فاكتور يا ضريب

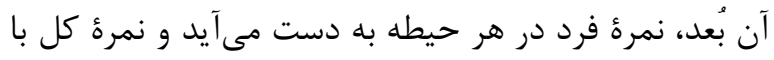
جمع كردن نمرات همهٔ حيطهها به دست مى آيد. محدوده نمره كل بين צr - T است كه نمرءٔ بالاتر نشان دهنده عملكرد

\begin{tabular}{|c|c|c|c|c|c|}
\hline حداكثر نمره & حداقل نمره & ضريب & محدوده نمرات & سؤالات & بخش \\
\hline 4 & $1 / r$ & $\cdot 19$ & $\Delta-1$ & 1.5 & ميل جنسى \\
\hline 4 & صفر & $\cdot \pi$ & صفر - ه & 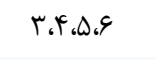 & برانگيختكى جنسى \\
\hline 4 & صفر & $\cdot / r$ & صفر - ه & 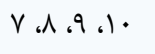 & رطوبت مهبلى \\
\hline 4 & صفر & $\cdot / f$ & صفر - ه & سו، זו، & اركاسم \\
\hline 4 & صفر & $\cdot / f$ & صفر يا 1 - ه & $1 f ، 10,18$ & رضايت جنسى \\
\hline 4 & صفر & $\cdot / 4$ & صفر -0 & $1 V .11 .19$ & درد \\
\hline
\end{tabular}

در نهايت براى تحليل دادهها از نرمافزار SPSS نسخه سب و متناسب با سطح (SPSS Inc., Chicago, Ill., USA) سنجش متغيرها از آمارهاى توصيفى (ميانگين، انحراف

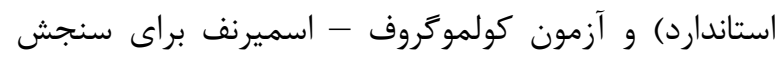
نرمال بودن توزيع نمرات، آزمون لوين براى سنجش يكسانى

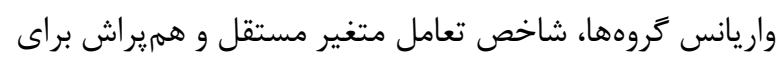
سنجش همخَنى شيبهاى رگريسيونى، و تحليل كوارياس و آزمون تعقيبى توكى (جهت بررسى تفاوت بين زروه ها)
شاخص عملكرد جنسى زنان در ايران توسط Mohammadi يايايى مقياس و خردهمقياسها را از طريق محاسبه ضريب

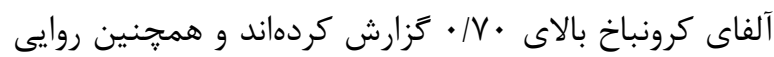

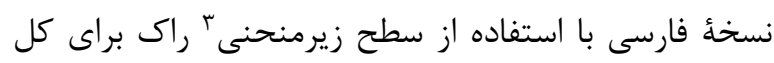

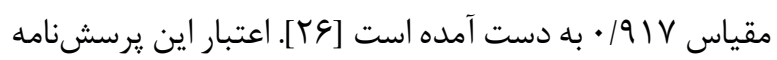

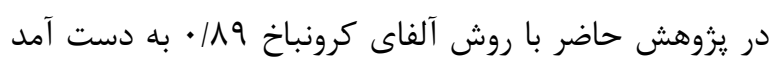
كه حاكى از اعتبار مناسب و قابل قبول آن است.

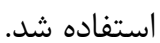

جدول r. خلاصه محتواى جلسات آموزشى زوجدرمانى شناختى - رفتارى استنتاج از Goldenberg و Goldenberg ترجمه Hamid Reza Hossein

\section{محتواى جلسات}

\section{حلسات}

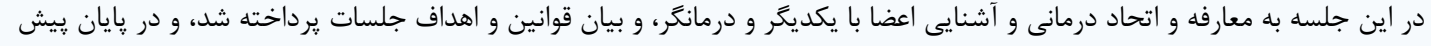

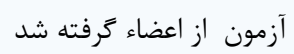

جلسه اول

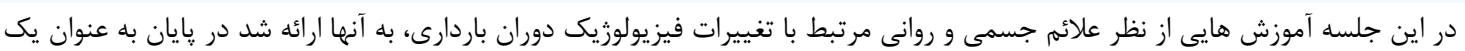

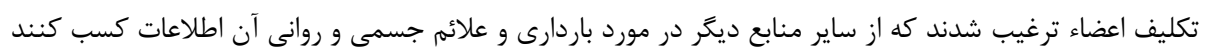

جلسه دوم

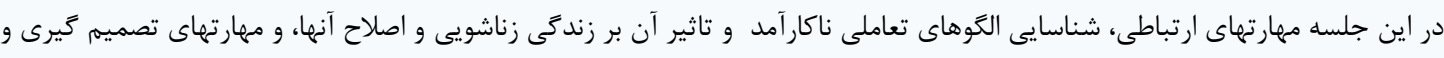

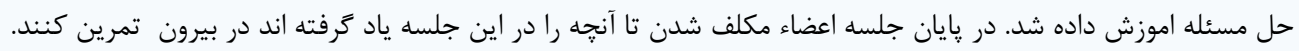

جلسه سوم

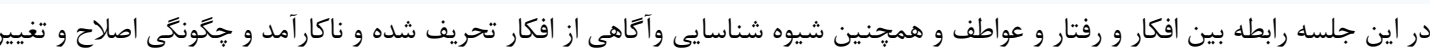

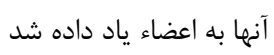

جلسه جهارم

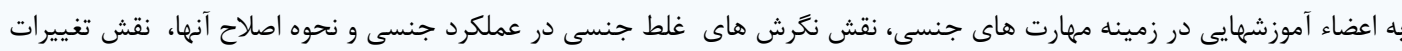

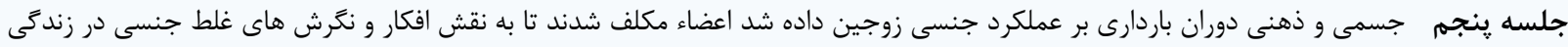
زناشويى خود بنكرند و سعى كنند آنها را اصلاح كنند

AUC: Area Under the Curve. 


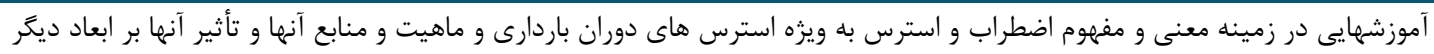

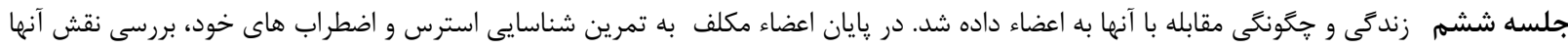

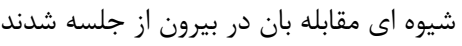

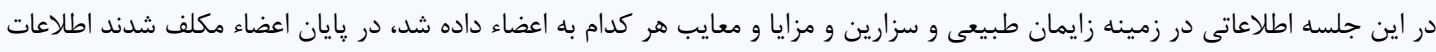
بيشترى از منابع معتبر ديكر كردآورى كنند.

حلسه هفتم

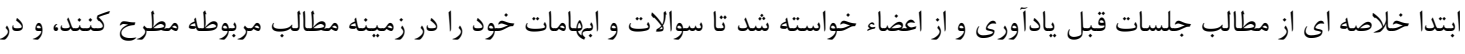

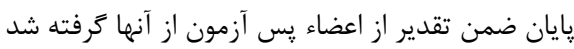
جلسه هشتم

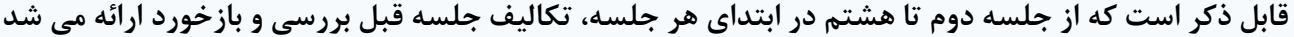

جدول ץ. خلاصه محتواى جلسات آموزش زوجدرمانى مدل EIS (همدلى، صميميت، رضايت جنسى) بركرفته از كتابجه راهنماى مدل [10] Konzen ،EIS

جلسات

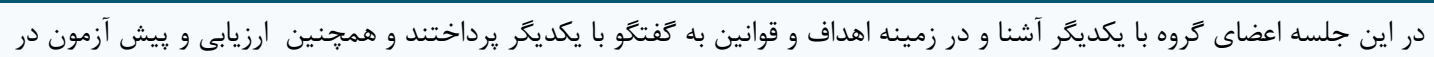

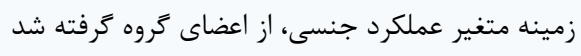

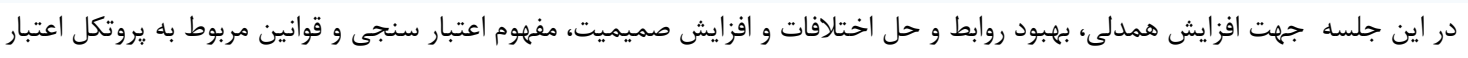

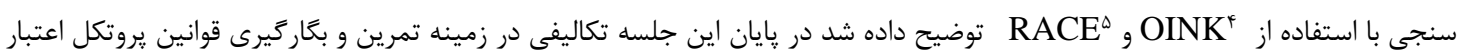

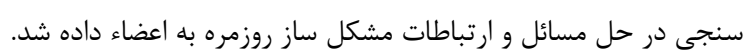

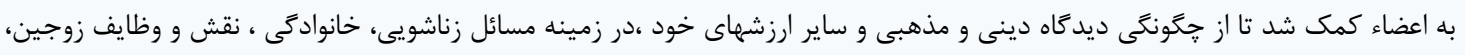

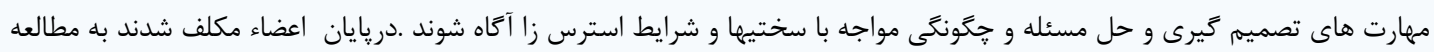

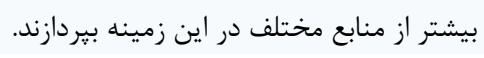

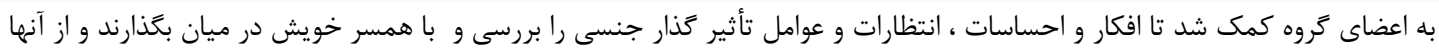

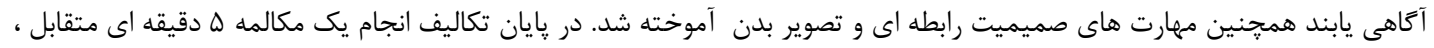

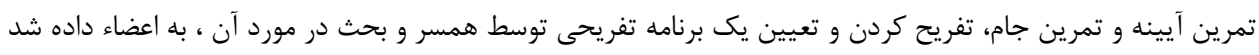

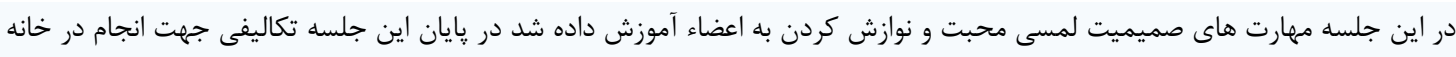

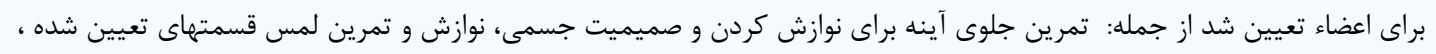

$$
\text { تمرين اعلام و انعكاس، }
$$

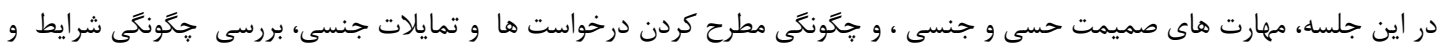

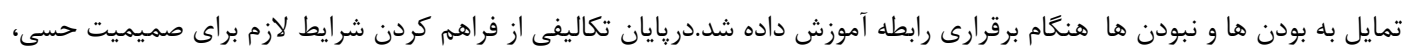

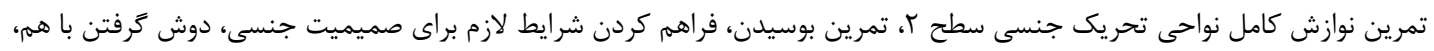

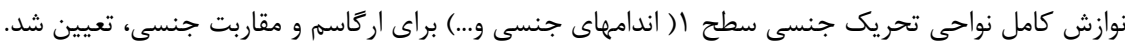

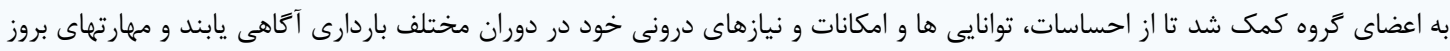

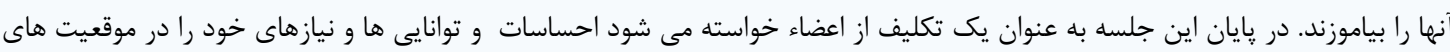

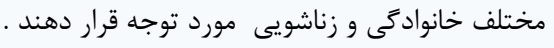

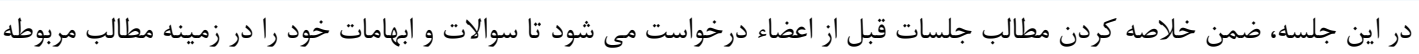


جدول f. اطلاعات جمعيت شناختى مشاركت كنندكان در يزوهش

\begin{tabular}{|c|c|c|c|c|c|c|c|c|c|}
\hline \multirow{5}{*}{ P-Value } & \multirow{5}{*}{ آزماره } & \multicolumn{6}{|c|}{ تروهاى نمونه } & \multirow{5}{*}{ سطح متغير } & \multirow{5}{*}{ متغيرها } \\
\hline & & \multirow{3}{*}{\multicolumn{2}{|c|}{ 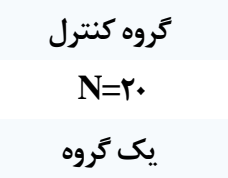 }} & \multicolumn{4}{|c|}{ كروههاى مداخله } & & \\
\hline & & & & & \multicolumn{2}{|c|}{$N=r}$. & & \\
\hline & & & & \multicolumn{2}{|c|}{ مدل EIS } & \multicolumn{2}{|c|}{ شناختى -رفتارى } & & \\
\hline & & درصد & فراوانى & درصد & فراوانى & درصد & فراوانى & & \\
\hline \multirow{2}{*}{$\cdot / 4 q$} & \multirow{2}{*}{$\cdot / 91$} & $V \Delta / \cdot$ & 10 & $\Lambda \cdot \%$ & 19 & $v \cdot /$ & if & خانه دارى & \multirow{2}{*}{ وضعيت اشتغال } \\
\hline & & $r \Delta / \cdot$ & $\Delta$ & $r \cdot \%$ & r & $r \cdot / \cdot$ & 4 & شاغل & \\
\hline \multirow{3}{*}{. } & \multirow{3}{*}{$\cdot / I F V$} & $\mathrm{r \omega} / \cdot$ & $\checkmark$ & $r \cdot / \cdot$ & $\wedge$ & $r \cdot / \cdot$ & 4 & دييلم & \multirow{3}{*}{ ميزان تحصيلات } \\
\hline & & $r \cdot \%$ & f & $1 . \%$ & r & $1 . \%$ & r & فوق دييلم & \\
\hline & & $F \Delta / \cdot$ & 9 & $\Delta \cdot \%$ & 1. & $4.1 \cdot$ & it & ليسانس و بالاتر & \\
\hline \multirow{4}{*}{.$/ 19$} & \multirow{4}{*}{$1 / \cdot r$} & $1 \cdot \%$ & r & $r \cdot / \cdot$ & f & $r \omega / \cdot$ & $\Delta$ & زير دييلم & \multirow{3}{*}{ ميزان تحصيلات همسر } \\
\hline & & $r \cdot \%$ & 4 & $r \Delta / \cdot$ & $\Delta$ & $r \cdot /$ & 9 & دييلم و فوق دييلم & \\
\hline & & $4.1 \cdot$ & it & $\Delta \Delta / \cdot$ & 11 & $\lceil\Delta / \cdot$ & 9 & ليسانس و بالاتر & \\
\hline & & \multicolumn{2}{|c|}{ ميانگين } & \multicolumn{2}{|c|}{ ميانگين } & \multicolumn{2}{|c|}{ ميانغَين } & - & - \\
\hline$\cdot|\Lambda|$ & $.199 \mathrm{~V}$ & \multicolumn{2}{|c|}{$r q / 4$} & \multicolumn{2}{|c|}{$r q / \cdot \Delta$} & \multicolumn{2}{|c|}{$r \cdot / \uparrow \Delta$} & - & سن \\
\hline$\cdot \pi \Lambda$ &.$/ 191$ & \multicolumn{2}{|c|}{$r / \Delta V$} & \multicolumn{2}{|c|}{$r / \Delta \Delta$} & \multicolumn{2}{|c|}{$F / T V$} & - & مدت زمان ازدوج \\
\hline
\end{tabular}

خردهمقياسهاى آن وجود دارد. همجنين براساس دادههاى

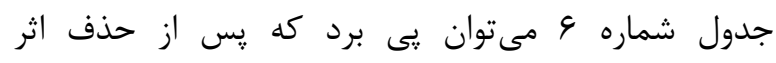

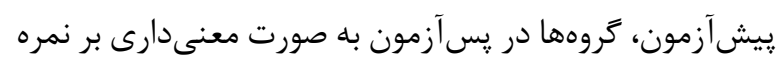

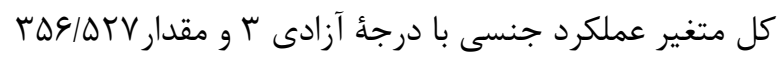

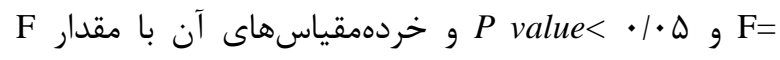

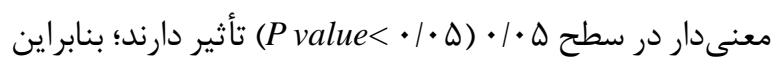

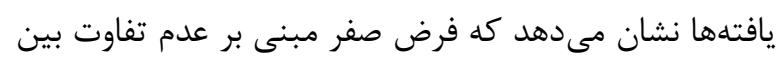

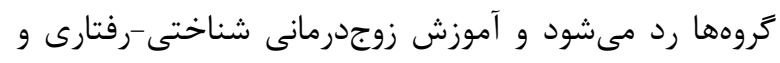

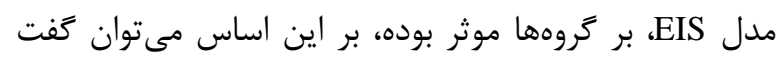

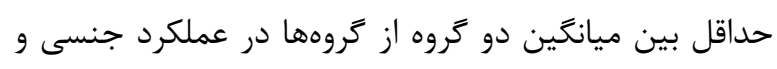

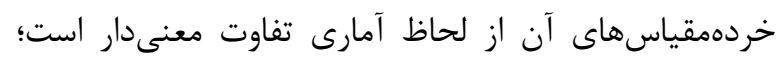

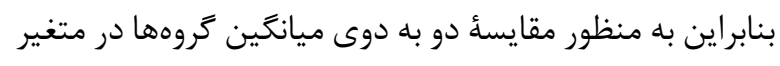

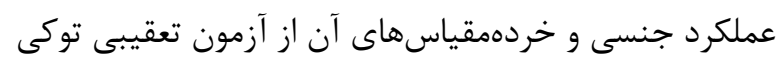
استفاده مىشود.
نتايج آزمونهاى كولموكروف-اسميرنف، آزمون لوين و

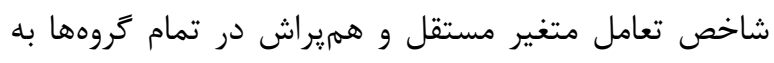

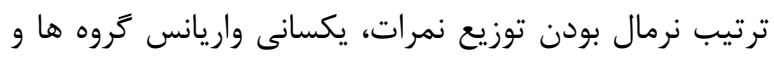

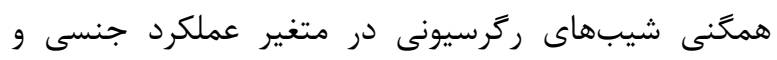

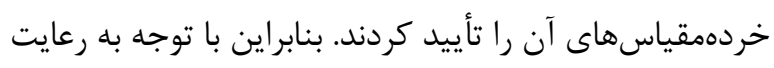

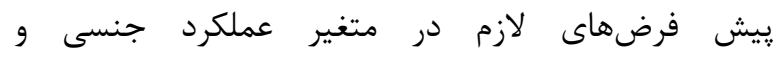

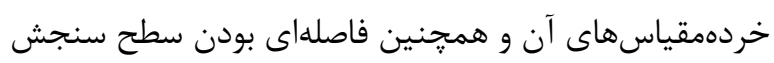

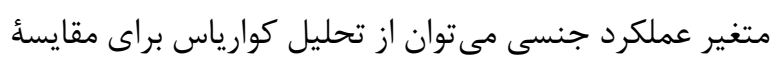

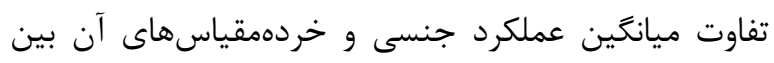
كروهها استفاد كرد. نتايج آزمونهاى لامبداى ويلكز در جدول شماره ها هاكى حانى

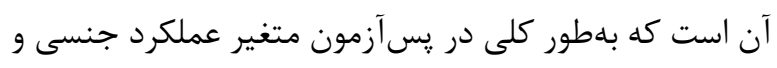

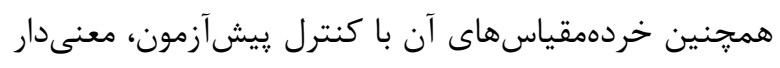

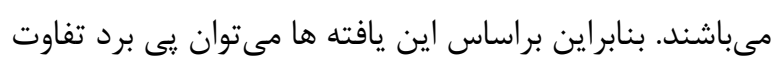

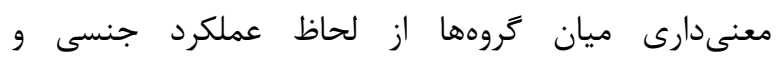




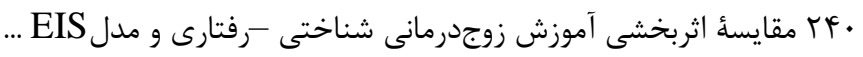

جدول ه. نتايج بر آمده از تحليل كواريانس جند متغيره (MANCOVA) براى بر رسى اثرات كلى روى تفاضل نمرات در بِ آزمون

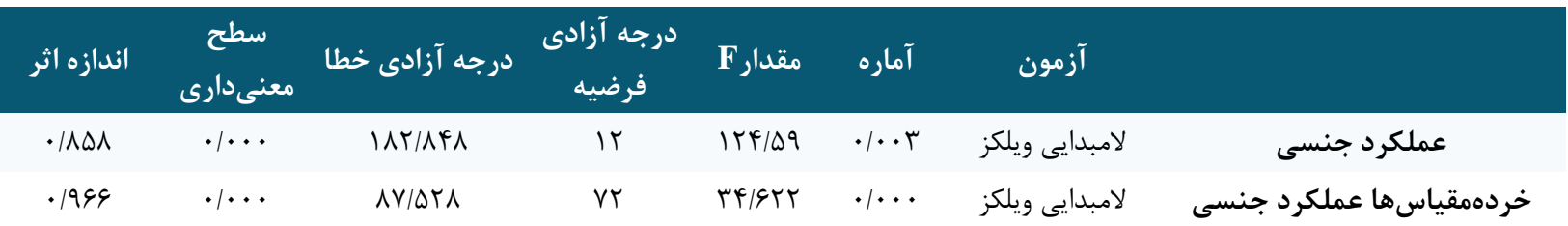

جدول 9. نتايج آزمون تحليل كواريانس هند متغيره نمرات عملكرد جنسى و خردهمقياسهاى آن در تروههاى مداخله وكنترل در

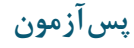

\begin{tabular}{|c|c|c|c|c|c|c|c|}
\hline اندازه اثر & Pقدار P P P & Fقدار F F F F F & ميانگين مجذورات & آزادى & مجموع مجذورات & \multicolumn{2}{|c|}{ متغير و خرده مقياس هاى آن } \\
\hline . $/ 9 \mathrm{YV}$ & $\cdot 1 \ldots$ & $r \Delta G / \Delta T V$ & $\Delta r q / \Delta / \Lambda$ & r & $1 \Delta \Lambda \Lambda / \Delta \Delta \Delta$ & & عملكرد جنسى \\
\hline $.19 \mathrm{VV}$ & 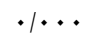 & $r 4 / r 91$ & $r \cdot 1 .+1$ & r & G./1Kr & ميل جنسى & \\
\hline$\cdot / \vee 91$ & $\cdot 1 \ldots$ & GN/TFY & Tr/Tr & $r$ & rब/ & برانكَيختكى جنسى & \\
\hline - /AVA & $\cdot 1 \cdot$ & ITK/KTM & $\mid V / F Y q$ & $r$ & DI/VEV & رطوبت مهببلى & خرده مقياس هاى \\
\hline$\cdot / \mathrm{N}$ & $\cdot 1 \ldots$ & $\Leftrightarrow 9 / 9 \Delta V$ & V/ANT & $r$ & TH/GYA & اكتاسم & عملكرد جنسى \\
\hline - /VVT & $\cdot 1 \ldots$ & DN/NFT & $11 / 111$ & r & $r \mu / r \Delta F$ & رضايت جنسى & \\
\hline - NFEA & $\cdot / \cdots$ & $\Delta \cdot / \Delta r \Lambda$ & $1 \cdot / r \cdot r$ & r & $r \cdot / 9.9$ & مقاربت دردناك & \\
\hline
\end{tabular}

اثربخشى آموزش زوجدرمانى شناختى-رفتارى و مدل EIS بر

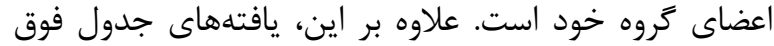

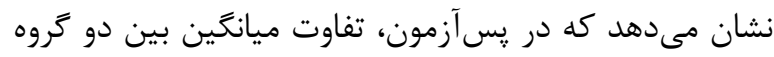

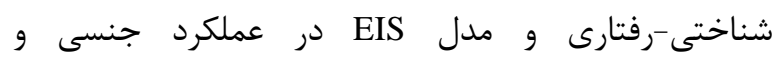

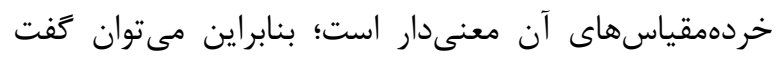

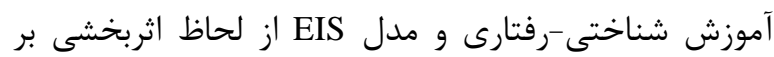

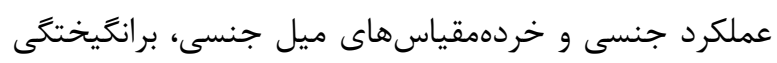

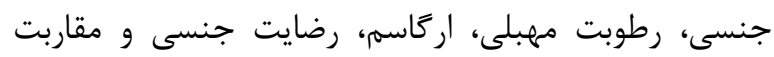
دردناك متفاوت هستند.
همجنان كه در جدول شماره V مشاهده مىشود تفاوت

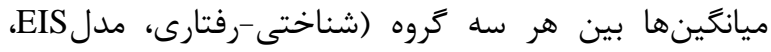

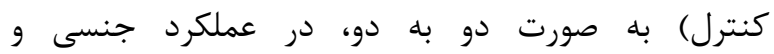

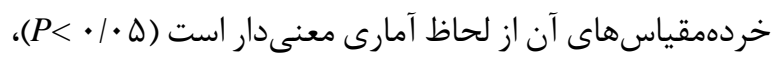

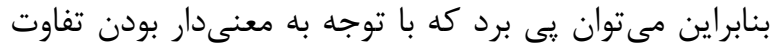

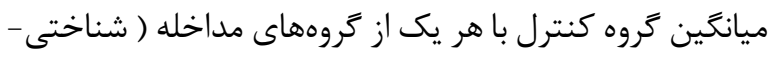

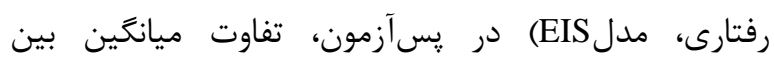

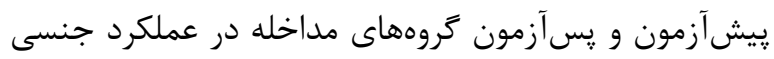

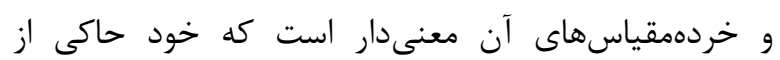

جدول V . نتايج آزمون تعقيبى توكى در هم سنجى دو به دوى متغيرهاى مستقل با توجه به متغير عملكرد جنسى و خر دهمقياسهاى آن در يس آزمون

\begin{tabular}{|c|c|c|c|c|c|c|c|c|c|c|c|c|c|}
\hline ا كنترل & مدل & 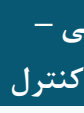 & 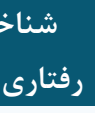 & $\begin{array}{l}\text { رفتارى| } \\
\text { EIS }\end{array}$ & 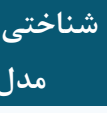 & EIS & مدل & 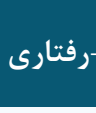 & شناختى & \multicolumn{2}{|c|}{ كنترل } & \multirow{2}{*}{\multicolumn{2}{|c|}{ متغير و خرده مقياس هاى آن }} \\
\hline sig & ميانغين & Sig & تفاوتخين & Sig & ميانغين & انحراف & ميانگَين & انحراف & ميانگين & انحراف & ميانكَين & & \\
\hline$\cdot 1 \cdots$ & $11 / V F$ & $\cdot 1 \cdot$ & D/r & $\cdot / \cdots$ & $9 / 0$ & $1 / \wedge \Delta$ & $r F / \cdot \Lambda$ & $1 / 1$ & $\mid V / \Delta \Lambda$ & $1 / 14$ & $\mid r / T F$ & د ج جنسى & عملكر \\
\hline$\cdot 1 \cdots$ & $r / F$ & $\cdot 1 \cdots$ & $1 / \cdot \Delta$ & $\cdot 1 \cdots$ & $1 / \pi \Delta$ & $\cdot / 91$ & $F / T q$ & $\cdot / \mathrm{VA}$ & $r / 91$ & $\cdot / F V$ & $1 / \wedge 9$ & ميل جنسى & \\
\hline$\cdot \cdots$ & $1 / 9 \Delta$ & $\cdot 1 \cdot$ & $1 / \pi \omega$ & $\cdot 1 \cdot r$ & $\cdot 19$ & $\cdot / \Delta V$ & $r / \mathcal{F}$ & $\cdot \mid \Delta V$ & $r / \Lambda \Lambda$ & • & $1 / \Delta r$ & جرانغيختىى & خاى عملكرد مقياس \\
\hline$\cdot 1 \cdots$ & $T / T \Delta$ & $\cdot 1 \cdots$ & $\cdot / 91$ & $\cdot / \cdots$ & 1/R & $\cdot / \Gamma \wedge$ & $f / r$ & - & T/QV & $\cdot \mid \Delta \Phi$ & $r / \cdot \Delta$ & رطوبت مهببلى & جنسى \\
\hline$\cdot 1 \cdots$ & $1 / \Delta 9$ & $\cdot 1 \cdot \cdot 1$ & $\cdot 109$ & $\cdot / \cdots$ & 1 & $\cdot / \pi \wedge$ & r & $\cdot \mid \Delta T$ & r & .199 & T/FF & اركاسم & \\
\hline
\end{tabular}




\begin{tabular}{|c|c|c|c|c|c|c|c|c|c|c|}
\hline كنترل & Eدل & كنترل & ر رفتارى & رفتارى| & ش مداختح & & مدل & شناختى -رفتارى & كنترل & \\
\hline sig & ميانكَين & Sig & ميانكَين & Sig & ميانكَين & انحراف & ميانََين & ميانكَين معيار & ميانكين معيار & \\
\hline$\cdot 1, \ldots$ & $1 / V \wedge$ & $\cdot / \ldots$ & .199 &.$\%$ & $1 / 1 r$ & $\cdot \pi \omega$ & $F / M \Lambda$ & $\cdot / \& \Delta$ & . & كنسى كي \\
\hline$\cdot 1$. & $1 / 1$ & $.1 \cdot .1$ & $\cdot / \mathrm{V}$ & $\cdot 1 \ldots$ & 1/1 & a & r/A & T/VG & $r / .4$ & مقاربت دردناك \\
\hline
\end{tabular}

$\cdot 1 \cdot \Delta \mathrm{p}<\%$

بحث

موجب رضايت جنسى، صميميت زناشويى و صميميت جنسى

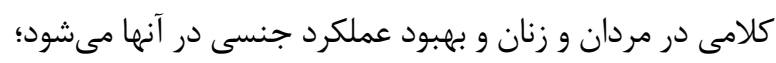

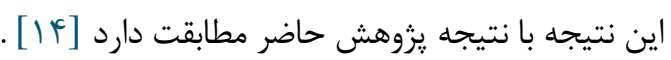

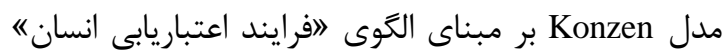

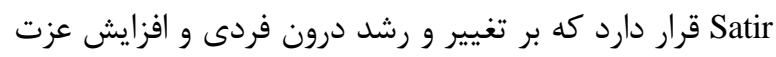

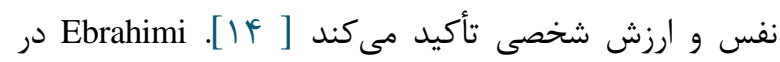

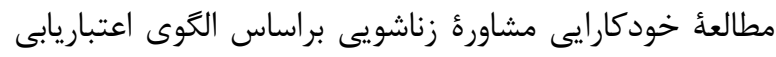

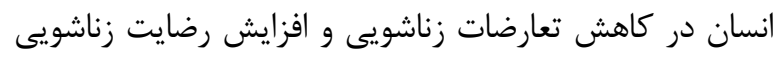

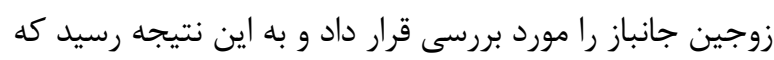

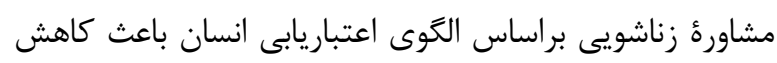

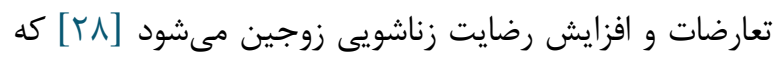

غيرمستقيم با نتيجه يزوهش حاضر مطابقت دارد. در مورد اثربخش بودنِ دو رويكرد شناختى -رفتارى و مدل EIS

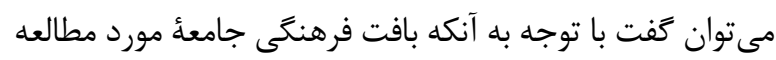

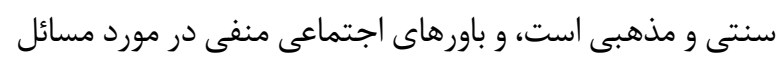

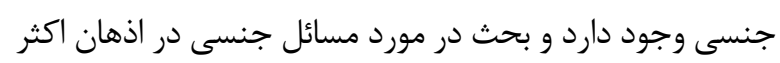

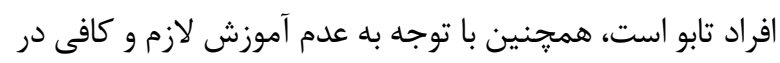

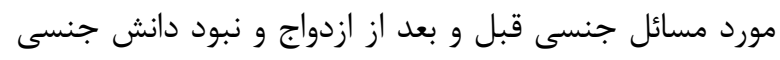

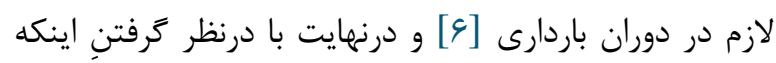

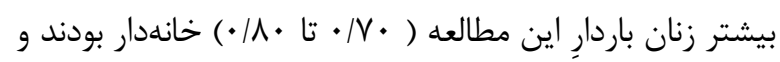

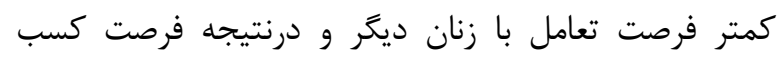

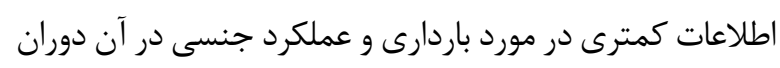

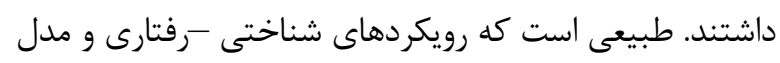

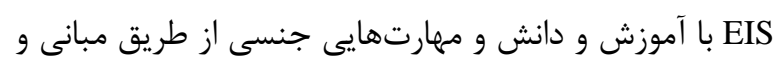

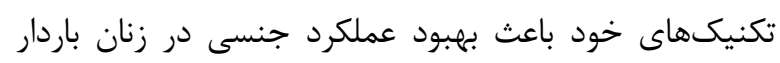

$$
\text { شوند. }
$$

اما در تبيين اينكه بين دو شيوه زوجدرمانى شناختى -

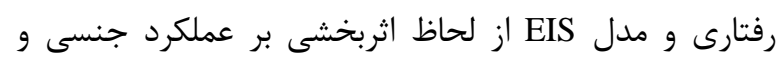

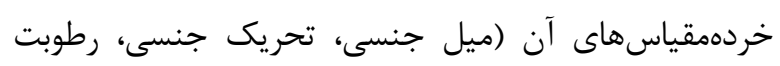

يزوهش حاضر با هدف مقايسٔ اثربخشى آموزش

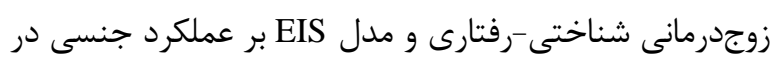

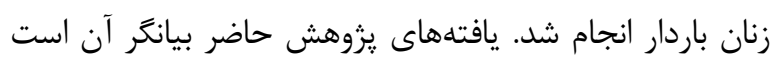

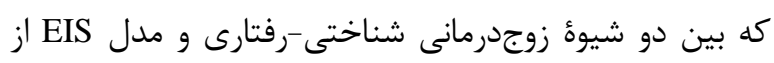

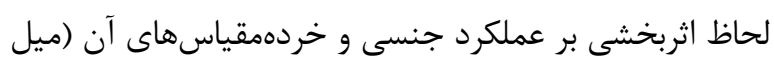

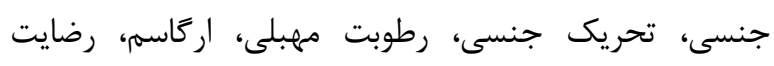

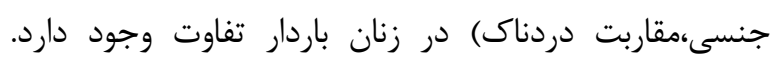

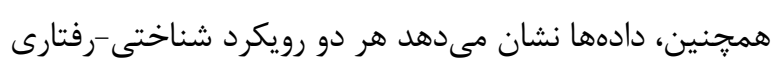
و مدل EIS بر عملكرد جنسى و خردهمقياسهاى آن(ميل

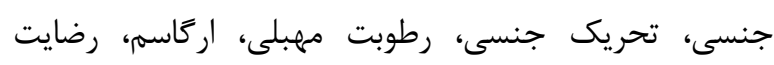

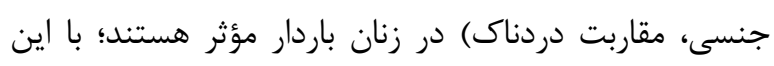

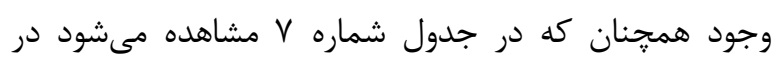

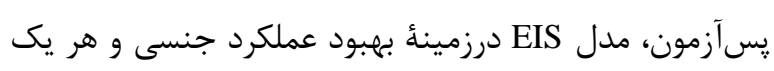

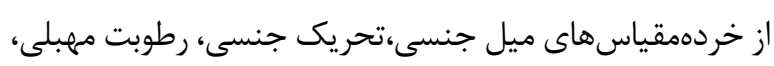

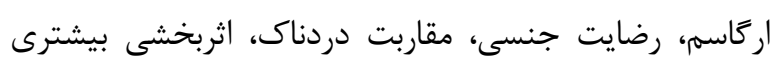

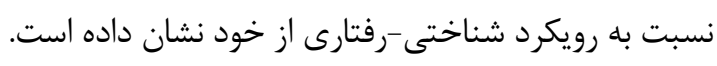

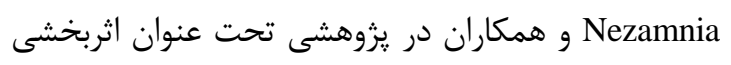

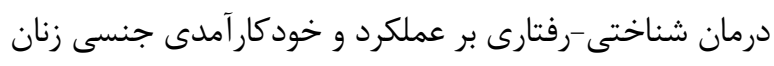

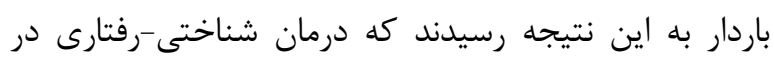

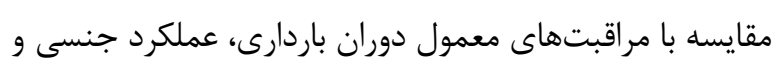

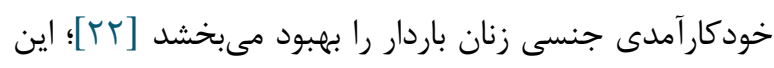

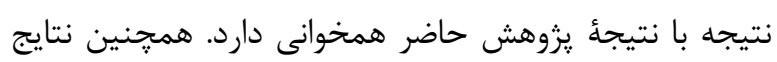

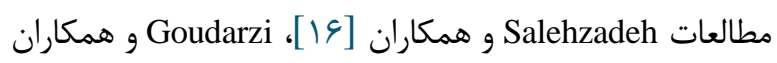

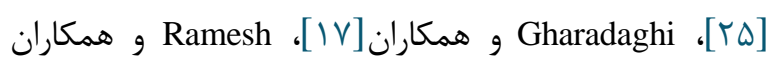

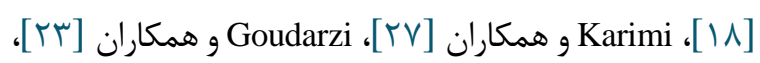

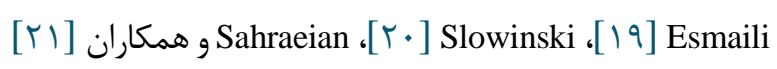
درزمينه عملكرد و رضايت جنسى و زناشويى مؤيد نتيجه

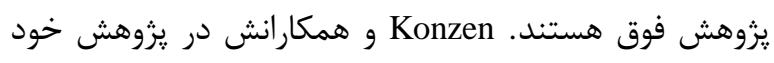

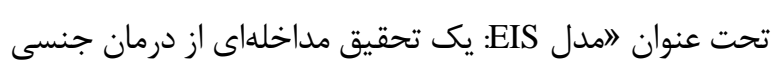

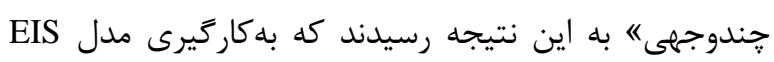




\section{نتيجه $\overline{~ ن ي ر ى ~}$}

براساس يافتههاى اين يروهش مىتوان نتيجه كرفت كه

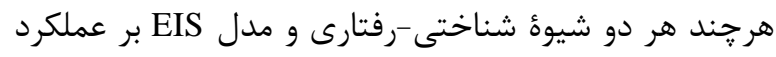

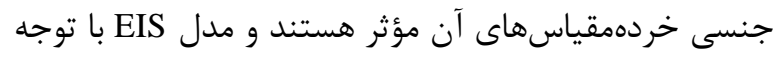

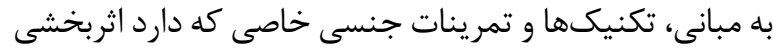

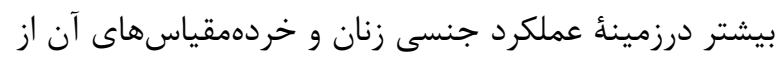

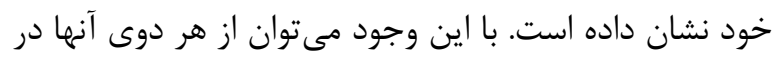

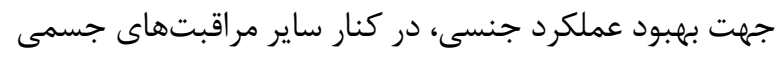

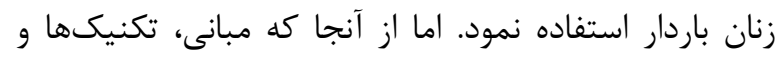

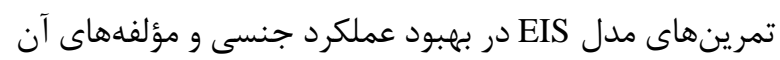

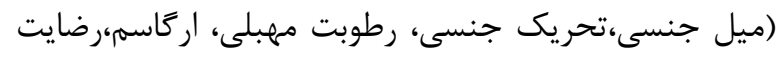

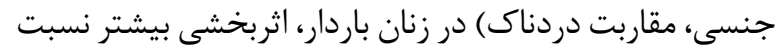

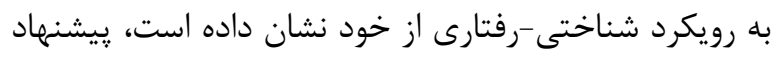

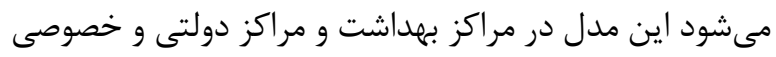

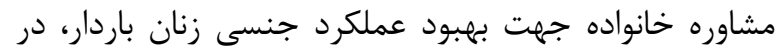

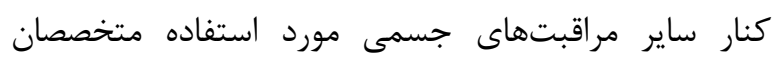
مربوطه قرار كيرد.

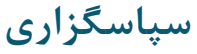

مقالهٔ حاضر بركرفته از باياننامه دكترى نويسنده اول در

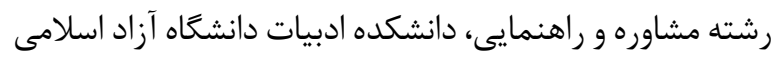

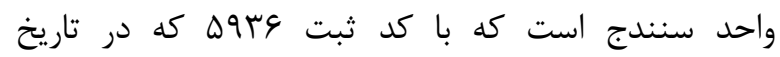

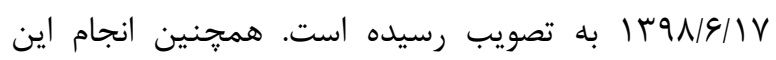

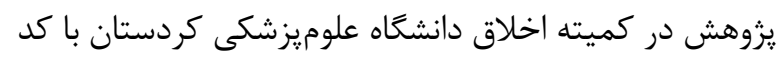
اخلاق (IR.MUK.REC.1398.279) تأييد شده است. در بر بايان

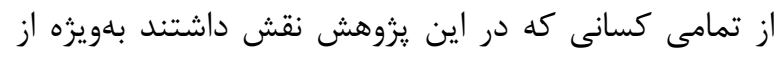

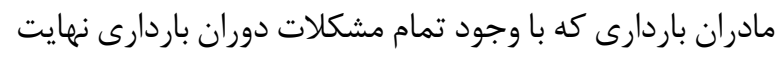

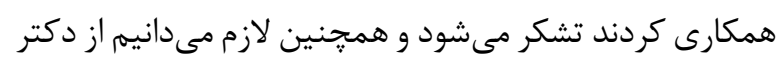

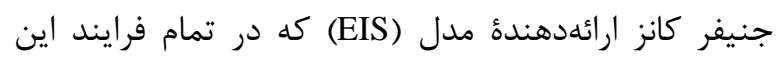
يزوهش ما را همراهى نمودند تشكر و قدردانى شود.

$$
\text { تعارض در منافع }
$$

بين نويسندكان هيج كَونه تعارضى در منافع وجود ندارد.

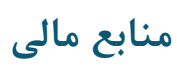

منابع مالى اين مطالعه توسط نويسندكان تامين شده است.
مهبلى، اركاسم، رضايت جنسى، مقاربت دردناك) در زنان باردار

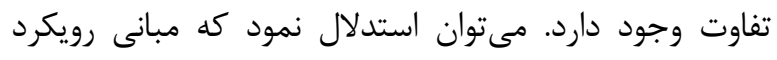

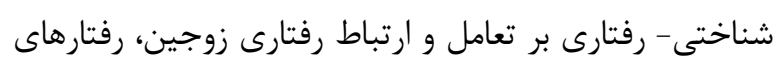

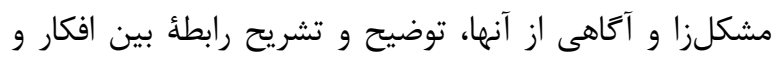

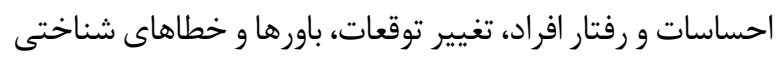
و شناختهاى غيرواقعى زوجين، بازسازى و تصحيح شناختهات باتهات

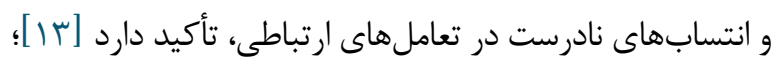
در حالى كه مدل EIS براساس رويكردهاى انسانى، تجربى و سيستمى استوار است و كمتر بر بُعد شناختى و و حلى حل مسئله

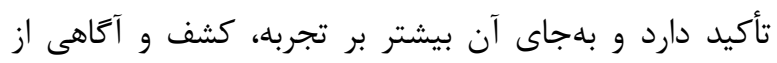

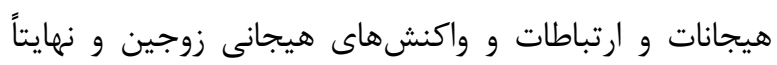

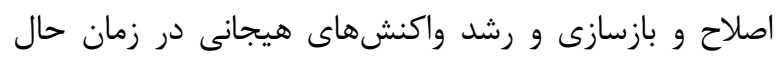

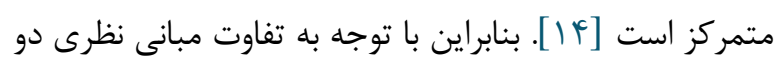

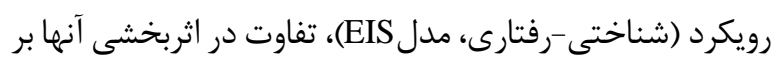

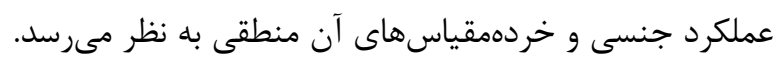

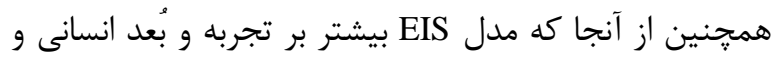

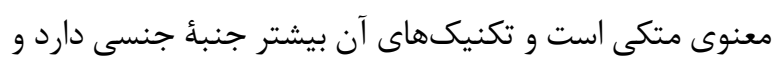

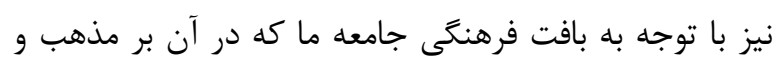

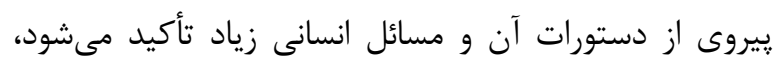

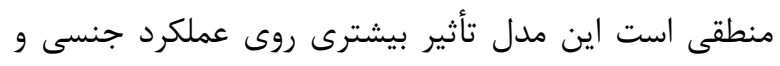

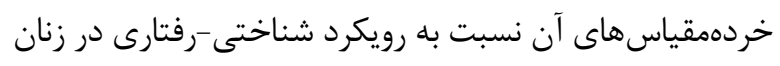

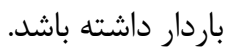
در يايان قابل ذكر است كه يزوهش حاضر با محدوديتهايى بارئ

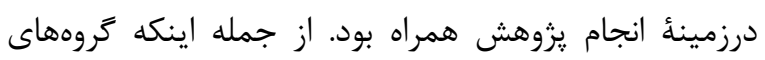

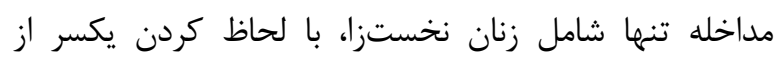

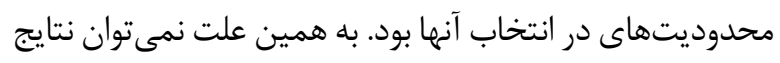

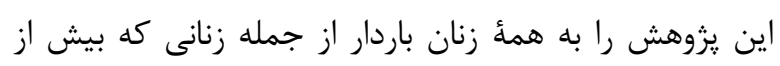

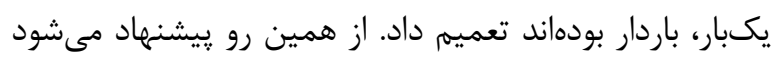

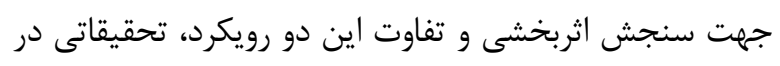

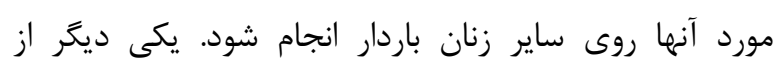

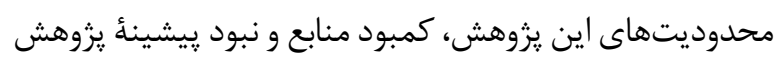

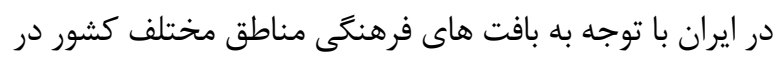

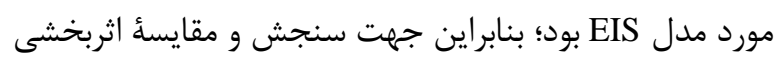

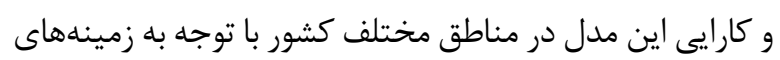
فرهنكى خاص خود، انجام تحقيقات بيشتر درزمينه عملكرد

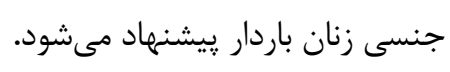




\section{References}

1. Jamali S, Rasekh Jahromi A, Zarei F, Sobhanian S. Compression of sexual dysfunction during three trimester of pregnancy in pregnant women who had referred to Peymanieh clinic Jahrom in 2013. Nurs Dev Health. 2014;5(8-9):37-45.

2. Shayan A, Khodabandeloo R, Solatani F, Esfandeh K, Masoumi SZ, Mohammadi Y, Dargahi S, Esmaili $\mathrm{M}$. The relationship between attitudes and sexual function in pregnant women referred to health centers-medical city of Hamadan. Pajouhan Sci J. 2020;18(2):20-9.

3. Khodakarami B, Masoomi SZ, Asadi R. The status and Marital satisfaction factors in nulliparous Pregnant females Atending clinics in Asadabad city. Avicenna J Nurs Midwifery Care. 2017; 25(1):52-8. [DOI:10.21859/nmi-25017]

4. Keley M. Mohammad Nazari A. Zahrakar K. The Experience of Pregnant Women about Sexual Relation during Pregnancy: A Phenomenological Study. J Qual Res Health Sci. 2018; 7(3):240-51

5. Baksu B, Davas I, Agar E, Akyol A, Varolan A.The effect of mode of delivery on postpartum sexual functioning in primiparous women. Int Urogynecol J. 2016; 18(4):401-6 [DOI:10.1007/s00192-0060156-0] [PMID]

6. Jones C, Chan C, Farine D. Sex in pregnancy. CMAJ. 2011; 183(7):815-8 [DOI:10.1503/cmaj.091580] [PMID] [PMCID]

7. Rostamkhani F, Ozgoli G, Merghati Khoei E, Jafari F, Alavi Majd H. Effectiveness of the PLISSITbased counseling on sexual function of women. $\mathbf{J}$ Nurs Midwifery 2012;22:1-9

8. Pasha H, HadjAhmadi M. Evaluation of sexual behaviors in pregnant women and some related factors. Hormozgan Med J. 2007;10(4):343-8.

9. Abbaszadeh F, Baghery A, Mehran N. Quality of Life among Pregnant Women. Hayat J. 2009; 15(1):41-8

10. Shoja M, Jouybari L, Sanagoo A. Changes in Sexual and Behavioral Relationships among Couples during Pregnancy. Qom Univ Med Sci J. 2011; 5(3):18-22

11. Zahra Karimi F, Dadgar S, Abdollahi M, Yousefi S, Tolyat M, Khosravi Anbaran Z. The relationship between minor ailments of pregnancy and quality of life in pregnant women. Iran J Obstet Gynecol Infertil. 2017;20(6):8-21.

12. Fathi A, Golakeh Khibari $S$. the relationship between prenatal concerns, depression and quality of life with general health of pregnant women. Nurs Midwifery J. 2018; 15(12):939-49.

13. Goldenberg I, Goldenberg H. Family Therapy. Translated by Hossein Shahi Braouti, HR, Naqshbandi Valham Arjmand, S; 19th edition; Tehran: Ravan Pub.
14. Konzen J, Lambert J, Miller M, Negash S. The Eis Model: A Pilot Investigation of A Multidisciplinary Sex Therapy Treatment. J Sex Marital Ther. 2018:218-54 [DOI:10.1080/0092623X.2018.1436626] [PMID]

15. Konzen J. Talking About Sex, Issues with Erectile Dysfunction, Issues with Erectile Dysfunction,Talking About Sex, Female Sexual Pain, Touch and Affection, Relationship Intimacy, Empathy: The Validator, Understanding Sexual Problems in Marriage: Intro

16. Salehzadeh M, kajbaf M, Mavlavi H, Zolfaghari M. Effectiveness of cognitive - behavior therapy on sexual dysfunction in women. Qua J Psych Stud. 2012; 7(1):24-9.

17. Gharadaghi A, Shafiabadi A, Hossein Rashidi B, Farhbakhsh K, Esmaeili M. Comparing the Effectiveness of Cognitive Behavioral Therapy (CBT) and Interpersonal Psychotherapy (IPT) for pregnant Women to Increase Marital Satisfaction. J Family Couns Psych. 2015; 4(4 Serial Number 16):583-605

18. Ramesh S, Rostami R, Merghati-Khoei E, Hemmat Boland E. Effectiveness of combination of cognitive-behavioral therapy and biofeedback on vaginismus patients' sexual function and marital status. Biann J Appl Psych. 2016; 6(1):1-22.

19. Esmaili M. The effectiveness of structured education on sexual function of pregnant women, Thesis submitted of achieve the degree of M.Sc. counseling in midwifery Field Qazvin, Qazvin, School of Nursing \& Midwifery, University of Medical Sciences; 2018.

20. Slowinski, J. Cognitive-Behavioral Therapy for Sexual Dysfunction, by Michael E. Metz, Norman B. J Sex Marit Ther. 2018; 44(8):806-7. [DOI:10.1080/0092623X.2018.1466946]

21. Sahraeian M, Lotfi R, Qorbani M, Faramarzi M. Dinpajooh F, Ramezani Tehrani F. the Effect of Cognitive Behavioral Therapy on Sexual Function in Infertile Women: A Randomized Controlled Clinical Trial. J Sex Marit Ther. 2019; 13(4):1-23. [DOI:10.1080/0092623X.2019.1594476] [PMID]

22. Nezamnia M, Iravani M, Sayyah Bargard M, Latifi M. Effectiveness of cognitive-behavioral therapy on sexual function and sexual self-efficacy in pregnant women: An RCT. IJRM. 2020; 18(8):62536. [DOI:10.18502/ijrm.v13i8.7504] [PMID] [PMCID]

23. Goudarzi M, Shiri F. Mahmoudi B. Effectiveness of Cognitive-Behaviora Family Therapy on parentchild conflicts and marital conflict. Appl Psych J. 2019; 4(48):531-51.

24. Hamedi B, Zarei S. The Effectiveness of the Marriage Enrichment Program Based on the Cognitive-Behavioral Approach on the Marital Intimacy of Addicted Man and their Wives. Quart J Res Addic. 2011; 4(16):93-102.

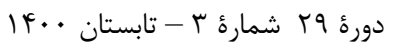


25. Goudarzi M, Boostanipoor A. Effectiveness of Systemic-Behavioral Couple Therapy on Marital Adjustment. J Family Couns Psych. 2013; 3(2):28296.

26. Mohammadi KH, Heydari M, Faghihzadeh S. The Female Sexual Function Index (FSFI): validation of the Iranian version. Payesh. 2008; 7(3):68-89.

27. Karimi N. Babakhani V. Effectiveness of cognitivebehavioral skills training on increasing sexual and marital satisfaction of couples, J Appl Res Behav Sci. 2016; 30(27).

28. Ebrahimi L.The Effectiveness of Marital Counseling Based on Human Validation Patterns in Reducing Conflict and Increasing Marital Satisfaction of Veterans' Couples. Women Soc J. 2018; 8(32):248-64. 